\title{
Environmental Journalism in Indonesia: In Search of Principles and Technical Guidelines
}

\author{
ANA NADHYA ABRAR \\ Universitas Gadjah Mada, Indonesia
}

\begin{abstract}
Environmental journalism in Indonesia has a long history. An important part of this history is the presence of the "environment" rubric in Tempo news magazine. It could be treated as one of the indicators of environmental journalism development in Indonesia. However, environmental journalists in Indonesia still have fundamental weaknesses. They do not feel honored to occupy their position, do not get much access to obtain accurate information, and do not obtain many public attentions. Then, how should the practice of environmental journalism be conducted? This study has examined three environmental news in Tempo news magazine from November 2018 to February 2019. They were qualitatively analyzed through some categories, namely writing form, writing type, writing target, angle, article structure, lead, writing content, and language style. This study finds that Tempo preferred to present environmental news in the form of in-depth reporting. Tempo has implemented a series of techniques that are important for reporting environmental issues. Presumably, this can be used as a kind of technical guidelines for other print media in reporting environmental issues in Indonesia. This study also proposes some principles of environmental journalism. First, the news should comprehensively report environmental issues. Second, environmental reports should strongly have committed to biocentrism ethics and sustainable development principles. The duty of environmental journalism is to criticize the government, while its main goal is educating the public and increasing their environmental participation. In the level of news policy, it is very important to have a special desk in the environment in the newsroom.
\end{abstract}

Keywords: Environmental journalism, Tempo news magazine, biocentrism, sustainable development, comprehensive news.

\section{INTRODUCTION}

Environmental journalism in Indonesia has a quite long history. It can be traced to the establishment of the Environmental Commission of the National Development Planning Agency in 1972. The environmental commission was chaired by Emil Salim, who at that time was also deputy chairman of the National Development Planning Agency. However, according to Widjanarka, as quoted by Abrar (1997), an environmental case that began to attract the attention of Indonesian newspapers was the case of pollution carried out by PT Semarang Diamond Chemicals (SDC). Abrar (1997, p. 32) has written, "The case that was popularly called the Mitsubishi case was sticking out, due to strong protests against the Japanese companies. It is considered as the beginning of the rise of environmental news in Indonesia".

Since the Indonesian government established the State Minister of Population and Environment in 1983, the level of responsive quality of the press towards environmental problems had tended to increase. This level reached its peak when Emil Salim served as Minister of Population and Environment for the second time, 1988-1983. It was at this time that the weekly news magazines such as Tempo and Editor began to have an "environment" rubric on a 
regular basis. However, according to Abrar (1997, p. 33), the term of environmental journalism began to be popular in Indonesia in 1992, in a "Workshop on Environmental Journalism", held by LKBN ANTARA and UNESCO in Jakarta, April 27-May 3, 1992. Thus, the term environmental journalism became popular in Indonesia almost 27 years ago, while the weekly Tempo news magazine has had the "environment" rubric since 35 years ago. This study considers the development of environmental news reported by Tempo weekly news magazine through the "environment" rubric can be one important indicator of the progress of environmental journalism in Indonesia.

Although Tempo has had the 'environment' rubric for 35 years ago, environmental journalists in Indonesia still have some fundamental weaknesses. They do not feel honored to occupy that position. They will feel satisfied when they become political reporters. They also began their careers by self-learning about how to report science and the environment. They also do not get much access, either to government agencies or companies to obtain accurate information about environmental realities.

Such conditions often make environmental reporters desperate so they leave their profession and then turn to become environmentalists. One of them is AG Irawan who had been an environmental reporter in Radar Jogja during the periods of 1999-2011. Radar Jogja (2019) has written about him, "With his background as a journalist, he often makes observations. He saw a lot of behavior of people who were ignorant of the environment." Does the public understand that it is neglecting the environment, for example, throwing all kinds of garbage into the river is dangerous for the environment? According to Irawan (Radar Jogja 2019), the public actually understands, "They realized it was wrong, but it was still done. Even though they live in the river border. They should understand the potential danger."

We have double problems. On the one side, environmental journalists do not feel proud of their profession. On the other hand, the public in general still ignores environmental issues and problems. Then, what should environmental reporters do to deal with this situation? How should the practice of environmental journalism be carried out?

To answer these questions, this study will observe three environmental news reported by Tempo news magazine from November 2018 to February 2019 as case studies to uncover how this magazine has practiced environmental journalism recently, to know what kind of principles they have kept and what type of techniques they have developed in reporting environmental news. This study assumes that environmental journalism in Indonesia to some extent would benefit and get some insights from the environmental journalism model that has been practiced by Tempo news magazine.

\section{LITERATURE REVIEW}

It is a very rare previous study discussing Tempo's investigative journalism regarding environmental news. The most relevant previous study was conducted by Silaningrum (2017) with the title "Menakar jurnalisme investigasi Tempo: analisis isi kualitatif berita investigasi majalah Tempo edisi 19-24 Desember 2016 tentang obral izin fakultas kedokteran (Measuring Tempo's investigative journalism: a qualitative content analysis of Tempo magazine investigative news 19-24 December 2016 edition concerning clearance sale of medical faculty permits)". In general, this research has been able to describe what and how Tempo's investigative journalism. 
Tempo began to freely use the term investigative journalism, according to Silaningrum (2017), after the collapse of the New Order regime. However, the stretch of Tempo's investigative journalism had begun to emerge in the New Order era. Silaningrum (2017, p. 23) wrote:

It is just at that time the term depth-reporting was better known to press workers to eliminate the impression of dismantling disgrace, errors or violations from the government. The depth of facts is used under the pretext to give a wider perspective to the audience. This was done to avoid the danger that hit the media and the press workers.

In the 1970s, investigative journalism was something strange. The practice was suppressed by the Indonesian government. However, in 1974-1975, the Indonesia Raya daily and the Tempo weekly news magazine managed to uncover mega corruption in Pertamina, the Indonesian Oil Mining Company. This coverage of the Pertamina scandal, according to Tempo (2011), became a milestone of investigative journalism in the early era of Tempo's birth. Tempo (2011, p. 19) wrote, "Tempo's news about Pertamina's debt crisis shocked the public. The chaotic Pertamina debt has a major impact on the national economy. As a result, Pertamina's President Director Ibnu Sutowo was removed from his position". This result has triggered Tempo to continue investigative journalism practices. Since then, Tempo has given its journalists the opportunity to practice investigative journalism and keep the spirit to open the truth to the public (Silaningrum, 2017).

\section{METHODOLOGY}

Aziz (1992) has stated that the investigative reporting forms are only two, namely feature and indepth reporting. Furthermore, Aziz (1992) has described the basic features in assessing features and in-depth reporting (Table 1), which would be used as a conceptual framework for this study.

Table 1: Basic characteristics of feature and in-depth reporting

\begin{tabular}{lll}
\hline \multicolumn{1}{c}{ Writing form } & \multicolumn{1}{c}{ Feature } & \multicolumn{1}{c}{ In-depth reporting } \\
\hline Writing type & $\begin{array}{l}\text { Bright } \\
\text { Profile } \\
\text { News feature } \\
\text { Popular scientific } \\
\text { Teaching something } \\
\text { Introducing something } \\
\text { Historical feature }\end{array}$ & $\begin{array}{l}\text { Interpretive reporting } \\
\text { Investigative reporting }\end{array}$ \\
& $\begin{array}{l}\text { Personal experience } \\
\text { Explain in detail }\end{array}$ & \\
Writing target & Single & $\begin{array}{l}\text { Explain in detail } \\
\text { Can be single, can be also more } \\
\text { Angle }\end{array}$ \\
& & $\begin{array}{l}\text { than one, usually presented in } \\
\text { the form of packages that are } \\
\text { divided into 2, 3 or more titles } \\
\text { Article structure }\end{array}$ \\
Lead & $\begin{array}{l}\text { Free } \\
\text { It is an attractive description that } \\
\text { arouses people's interests }\end{array}$ & $\begin{array}{l}\text { Free } \\
\text { It is an attractive description that } \\
\text { arouses people's interests }\end{array}$ \\
\hline
\end{tabular}




\begin{tabular}{lll}
\hline Writing content & Factual, the answers to $5 \mathrm{~W}$ and & Factual, the answers to 5W and \\
& $\mathrm{H}$, although it doesn't have to be & $\mathrm{H}$, although it doesn't have to be \\
always complete (except for & always complete (except for \\
news features), with more & news features), with more \\
& $\begin{array}{l}\text { attention to the elements of why } \\
\text { and how }\end{array}$ & $\begin{array}{l}\text { attention to the elements of why } \\
\text { and how }\end{array}$ \\
& $\begin{array}{l}\text { Thrifty, clear, narrative, colorful, } \\
\text { Language }\end{array}$ & $\begin{array}{l}\text { Thrifty, clear, narrative, colorful, } \\
\text { idiomatic }\end{array}$ \\
\hline
\end{tabular}

This study has analyzed three environmental news that has been reported by Tempo News Magazine, as follows:

Table 2: Research materials

\begin{tabular}{lc}
\hline \multicolumn{1}{c}{ News title } & \multicolumn{1}{c}{ Reported on } \\
\hline $\begin{array}{l}\text { Hutan binasa, sawit tak ada (Perishable forests, no palm } \\
\text { oil) }\end{array}$ & 26 November-2 December 2018 \\
$\begin{array}{l}\text { Malapateka limbah Freeport (The disaster of Freeport } \\
\text { waste) }\end{array}$ & 18-25 January 2019 \\
$\begin{array}{l}\text { Limbah berbahaya di markas tentara (Hazardous waste } \\
\text { at the army headquarters) }\end{array}$ & 18-24 February 2019 \\
\hline
\end{tabular}

These three news were chosen since they resulted from investigative works conducted by special teams, consisting of project leaders, writers, editors, and so on. In other words, the processes of reporting the news were done carefully and went through careful planning. This study has conducted a qualitative content analysis of these three research materials using the conceptual framework as mentioned beforehand. This research strategy is in accordance with Holsti $(1969$, p. 2) who has defined content analysis as "a technique for drawing conclusions by identifying various specific characteristics of a message objectively and systematically".

\section{RESULT AND DISCUSSION}

\section{Tempo Reports on Environmental Issues}

This study finds that that Tempo preferred to present environmental news gathered from the investigation in the form of in-depth reporting. It consumes significant pages of the magazine. The audience has to allocate time to finish reading it.

Table 3: Writing form and type of the Tempo environmental news

\begin{tabular}{lcc}
\hline \multicolumn{1}{c}{ News Title } & Writing Form & Writing Type \\
\hline Hutan binasa, sawit tak ada (Perishable & In-depth & Investigative \\
forests, no palm oil) & reporting & reporting \\
Malapetaka limbah Freeport (The disaster of & In-depth & Investigative \\
Freeport waste) & reporting & reporting \\
Buanglah limbah pada markasnya (Dispose & In-depth & Investigative \\
hazardous waste at the army headquarter) & reporting & reporting \\
\hline
\end{tabular}


We should thank Tempo. Without their investigative reports, we would never know about the game behind oil palm licenses in Papua Province, a disaster caused by PT Freeport, and the waste business carried out by the Indonesian National Army. It seems that we should also praise the courage of Tempo journalists who have succeeded in revealing the truth about the cases being reported.

As mentioned in Table 3, the writing style of all news is investigative reporting. This type of news should be comprehensive news, having primary, secondary and tertiary events (Oetama, 2001, p. 280). Not surprisingly, the complete news is written in several titles. The first news, "Hutan binasa, sawit tak ada" (Perishable forests, no palm oil) consists of four titles, namely: (i) "Main-main izin sawit" (Playing palm oil permits), (ii) "Berebut hutan Boven Digul" (Fighting over Boven Digul forest), (iii) "Derita rimba Papua" (Papua's jungle suffering), and (iv) "Tanpa uang, enggak akan kuat" (Without money, will not be strong).

The second news, "Malapateka limbah Freeport" (The disaster of Freeport waste) also consists of four titles, namely: (i) "Patah sagu, ikan tak berganti" (Broken sago, fish does not change), (ii) "Limbah Rp 185 triliun" (Waste of Rp. 185 trillion), (iii) "Kami sudah prediksi dampak tailing" (We have predicted the impact of tailings), and (iv) "Isu lingkungan tidak gugur oleh divestasi" (Environmental issues are not stopped by divestment).

The third news, "Limbah berbahaya di markas tentara" (Hazardous waste at the army headquarters) is divided into three titles, namely, (i) "Buanglah limbah pada markasnya" (Dispose the waste at the headquarters), (ii) "Lumpuh terpanggang abu panas" (Paralyzed baked hot ash), and (iii) "TNI memang ada nakalnya" (TNI does have mischief).

From the lead, we may say that Tempo tried to catch the readers' completing to read the news from beginning to end. Such an attractive lead is intended to increase the interest of readers to enjoy and continue their reading consciously. Therefore, they will not miss any important information presented. The following leads can be the examples:

With a full load, heavy, and covered with tarpaulin, six trucks with a capacity of 25 tons go hand in hand in the north coast route of Pasuruan-Probolinggo, East Java, September 28, 2018 afternoon. The truck drove slowly and slowly as it approached the Indonesian Air Force Detachment Headquarter at Raci, Bangli, Pasuruan (Lead of the news titled "Buanglah limbah pada markasnya" - Dispose the waste at its headquarter).

One by one the boarding house door in a narrow alley of densely populated settlements in Menara Air Street, Manggarai, South Jakarta, was open. The residents inclined their heads when they heard Martyaningsih speak. The tone of this 58-year-old woman voice hardens when talking to Tempo (Lead of the news titled "Main-main izin sawit" - Playing palm oil permits).

From the writing target, we may conclude that Tempo regards the three news is very important. Tempo has explained in detail the object being reported in order to uncover all relevant events. This detail is deliberatively motivated to raise public awareness about what really happened. The following quotes from Tempo news show this aspect. 
The motive for getting wood behind the request to build oil palm plantations in Indonesia's forests is apparently the general mode of businessmen. Forest Timber Utilization Permit (IPKH) can increase the value of shares due to high value timber assets. This is evident in Tadmax's shares on the Malaysian stock exchange after the acquisition of Menara's subsidiary and the announcement of a timber value of Rp 12 trillion. So it is not strange if they dare to buy two Menara companies worth the US $\$ 80$ million (Excerpt from the news titled "Main-main izin sawit" - Playing palm oil permits).

Therefore, Chairul Anhar threatened to sue the Governor of Papua and the Regent of Boven Digoel to the State Administrative Court. In fact, the revocation of IUP continues to run. Finally, Governor Enembe revoked the IUP of PT Manunggal Sukses Mandiri, which has a palm oil concession covering 39 thousand hectares, last August. "That is our land," Chairul said. "It has not been cultivated, but the land still has its owner" (Excerpt from the news entitled "Berebut hutan Boven Digoel" - Fighting over the Boven Digoel forest).

These detail descriptions are also completed with multisided angles. The angle chosen by Tempo in reporting investigative coverage is of course in accordance with its editorial politics. What is their politics of editorship? Consider the following Tempo confession:

For us, investigative reporting has two strategic functions. First, this approach is still needed because the practice of corruption has not diminished. The fraud included making the price of drugs more expensive, high school fees, prices of basic necessities soaring, as well as inefficient people's justice. With investigations, some crimes that harm the public can be revealed.

The second function, investigative reporting provides much more accurate information to the public. In the midst of a flood of 'information' - most of which has not been verified - people can get lost when they have to make a decision. We believe that the investigative approach is more meaningful at this time (Tempo, 7-13 March 2016, p. 33).

The angle of the news entitled "Buanglah limbah pada markasnya" (Dispose of waste at its headquarter) was a misuse of a permit with an underhand agreement. Hazardous and toxic waste (B3) are dumped and buried in eight army bases in East Java. As a result, the army headquarter earned around Rp. 16 billion per year. However, they have injured the surrounding population and killed crops in the rice fields. In the news entitled "Lumpuh terpanggang abu panas" (Paralyzed baked hot ashes), Tempo picked out the angle from the residents who have suffered many injuries, ranging from legs, thighs, hands to buttocks, after they passed through vacant land that became a B3 landfill. 
In another news, "Limbah itu aman" (Waste is safe), the Tempo has presented the opinion of the Head of the Indonesian Air Force's Information Service, First Marshal Novyan Samyoga, who said that the laboratory results of the waste showed that all of the substances were still safe. He claimed to have laboratory evidence. However, the evidence was never presented to Tempo. While, in "TNI memang ada nakalnya" (TNI does have mischief), Tempo presented the opinion of the Head of the East Java Environment Agency, Diah Susilowati, who has argued that TNI had mischief. With all these angles, Tempo has actually provided accurate and complete information about hazardous waste at the army headquarters. Tempo has exposed the cheating practice at the army headquarters.

The three news also shows that news content is not only the answers of $5 \mathrm{~W}+1 \mathrm{H}$ questions but have deeply explored the questions of "why" and "how". Such exploration would enable the journalists to comprehensively write down the relationships of the primary events with the secondary and the tertiary events. They can write a long story and uncover the hidden situation so far.

In the investigative news entitled "Hutan binasa, sawit tak ada" (Perishable forests, no palm oil), the primary event was the cancellation of the conversion of forests into oil palm plantations in Boven Digoel Regency, Papua Province. Even though the forest has been destroyed. The environmental tragedy is just a matter of time. After having the observation, Tempo found a secondary event, namely Menara Group, the owner of the Forest Area Release Permit (IPKH), who has canceled planting of palm oil, sold the permit to another company and built infrastructure in Boven Digoel Regency. Of the seven Menara Group subsidiaries, which have IPKH covering 280 thousand hectares, two companies were sold to Tadmax Resources Bhd for the US $\$ 80$ million and four other companies were sold to the Middle East companies. The sale of IPKH, in addition, to bring money to Menara Group, also to save them from legal sanctions of violating the maximum area of ownership of 200 thousand hectares per business group. It was not open to the public at all. Further, Tempo found a tertiary event, namely the Minister of Forestry, Zulkifli Hasan, had made it easy for Menara to obtain a permit.

In the language presentation level, in order to keep the interest of the reader, Tempo has presented the news in thrifty, clear, narrative, colorful and idiomatic ways through journalistic languages. For Tempo, such journalistic language is important to guarantee their journalist to be able to write about what they have seen, felt and heard. Their journalistic language is sparing with words, the fabric of the story is clear, and the description is solid. It has confirmed Rosihan Anwar (1984, p. 1), a senior Indonesian journalist, who has identified journalistic language as having certain features, i.e. short, compact, simple, fluent, clear, straightforward and interesting traits. Moreover, Tempo not merely incised words and sentences, but they have tried to familiarize the readers with the literacy about environment, nature, and people. The following news excerpt shows this language style.

Dead elephants leave ivory, Freeport-McMoRan goes, leaving tailings. The US giant that has been mining gold in Papua since 1967 has not been the majority owner of PT Freeport Indonesia shares after the government, through PT Indonesia Asahan Aluminiun (Inalum), bought 51.2 percent of its shares for the US $\$ 3.85$ billion or around Rp 55, 8 trillion in the middle of last December. 
The government finally relented by not requiring the terms of settlement of gold production waste dealings in the transaction, which isolated four districts of 7,506 people in Mimika Regency. In fact, in the 2017 audit report, the Supreme Audit Agency announced the potential for environmental damage due to waste that leaked into settlements, killed sago fields, and deprived residents of livelihoods of Rp 185 trillion (News excerpt entitled "Malapetaka limbah Freeport" - The disaster of Freeport waste).

Some Principles and Techniques for Environmental Journalism in Indonesia

In the following section, I am going to propose some insights that Indonesian environmental journalists could make use of them, namely comprehensive news, commitment to biocentrism and sustainable development, criticizing the government, educating and increasing public engagement, and changing the newsroom. These insights are generalized from my broad and longtime observations to the development of environmental news in Indonesia, and especially from the Tempo environmental news that has been analyzed.

\section{a. Comprehensive Reports}

Investigative journalism, according to Silaningrum (2017, p. 85), can be defined as "Investigative journalism is journalism that aims to uncover cases of violations of public interest". Silaningrum (2017, p. 16) also said, "It combined the four techniques to gather facts, starting from observations, interviews, press releases, and press conferences. It produced relatively complete facts".

In order to meet investigative news qualifications, according to Oetama (2001), the reporters should write comprehensive news. They are not enough just to do factual reportage or report only on one aspect, but they have to obtain comprehensive facts and do extensive observations. Oetama (2001, p. 277) has emphasized, "There are a way and a style of journalistic research called the investigative report". To get complete environmental news, Fletcher and Stahlbrand (1992, p. 184), borrowing Andrew Nikiforuk's opinion, suggested that "environmental news not only presents the effects of an environmental reality on nature but also its relation to political, social and economic aspects".

Tempo's investigative journalism usually presents confidential sources. Lukas Deni Setiawan's research on Tempo news about the corruption scandals from January 2011 to October 2013 has shown that the use of confidential sources reached $36.5 \%$ (Silaningrum, 2017). It seems to be one of the characteristics of Tempo's investigative journalism. The use of secret sources is of course to reveal hidden facts. It is indeed this depth of fact that distinguishes investigative journalism from ordinary journalism (Kurnia, 2009, p. 233).

\section{b. Commitment to Biocentrism and Sustainable Development}

Another important insight we should explore is how Tempo magazine identifies environmental problems. Does the problem only matter for the human interests and profit values or for the benefit of the environment itself? Seeing environmental problems merely from human interests are classified as anthropocentrism. Keraf $(2002$, p. 33) has noted this kind of perspective, "Even nature is seen only as an object, a means of fulfilling human needs and interests. Nature is only 
a tool for achieving human goals. Nature has no value in itself". Another much better ethics is called biocentrism. Regarding biocentrism, Keraf (2002, p. 49) has emphasized, "For biocentrism, it is not true that only humans have values. Nature also has value in itself apart from human interests".

This fundamental ethics towards the environment is also closely related to the issue of sustainable development. In general, commitment to biocentrism ethics will also drive a commitment to sustainable development. According to Emil Salim (2013), a reasonable way to preserve our environment is to practice sustainable development. Salim (2013, p. 11) has noted:

The idea of "sustainable development" must be endeavored to become a continuous stream of global and national development through high-level conferences held every decade, the Rio 1992 Earth Summit, the 2002 Johannesburg Earth Summit, and the Rio 2012 Earth Summit.

The three environmental news reporting by Tempo shows a biocentrism point of view. Instead, through the three news stories, Tempo even sees the government has applied the anthropocentrism standpoint in managing the environment. I would also argue that Tempo environmental news has already supported sustainable development.

It could be the inspiration for Indonesian environmental journalists to look at environmental issues. Everything that goes against sustainable development must be seen as something that will cause environmental problems. All government responses to environmental issues must be reported. Ideally, the responses must be an integral part of the sustainable development policies of the country (Salleh \& Ghaffar, 2009, p. 77). However, reality is somehow usually very far away from that kind of ideality. Thus, it is the duty of environmental journalists to hunt facts about government mistakes, in order to criticize and push them to apply sustainable development principles.

However, the internal conditions within environmental journalists in Indonesia need to be upgraded to develop the commitment to biocentrism as well as to sustainable development. One of the very basic problems is about the bias of the environmental news, namely framing certain environmental problems not as environmental issues, but as social, political, economical, or another issue. Aditjondro (2003, p. 47) has emphasized:

Finally, let us look at news bias, where events are only reported as social problems, ignoring the ecological implications of these events. For example, the eviction of thousands of rickshaw in Jakarta was only reported as a social problem, while the greenhouse effect of hundreds of thousands motorized vehicles substituting rickshaw was not questioned by the press.

This quote shows that environmental issues are not simple. We may ask questions about the level of understanding of environmental journalists who write the news. We may also ask questions about the attitude of the press that broadcast the news towards environmental problems. 


\section{c. Criticizing The Government}

Generally, the public reads environmental news not only to gain awareness, but they want to know their position when dealing with nature. They want to convince themselves whether they are a jerk or not. At the same time, they also want to know how the state manages nature or give permission to companies to manage nature. If the state is indeed evil towards nature, they want the press to express it firmly.

The three environmental news reporting by Tempo indeed shows how evil the government is towards nature. In the first news, the government just let the negative environmental impacts occur because of granting palm plantation licenses in Papua Province. The permit recipient did not really mean to build oil palm, even though the forest has been cleared.

In the second news, Tempo shows that the government has also allowed tailings to convert clear rivers into extensive arid land and former mines that damaged environmental functions. The government is powerless to face Freeport's progress. The government does not guarantee that future generations around the Freeport mine areas will inherit nature at least the same as the current generations.

In the third news, Tempo shows that the military headquarters in East Java were actually stockpiling toxic waste, from which they get relatively much money. In order to get the money, they do not care about the health of the communities around toxic waste disposal. Those who are supposed to protect the community, malpractice to harm the community. A number of factors can explain why the army commit such a disgraceful act. One of them is the national leadership factor. According to Sujito (2013, p. 115), the national leadership is now shrinking. As a result, national values also shrink. It is not surprising that the political elites feel innocent with all the problems that occur in the government.

With all these government problems reported in the news, readers will be more critical towards the government, also be more skeptical of the information about the government's performance.

\section{d. Educating and Increasing Public Participation}

However, it does not mean that Tempo is anti-government or anti-military. Tempo only prioritizes public interests and tries to educate the public to have high environmental awareness. It corresponds to the roles of environmental news, namely educating journalists, educating the public, and overseeing the government (The Asia Forum of Environmental Journalists, 1988, pp. 22-24). It seems that the ultimate goal of environmental news is to educate the public to care for the environment. This final goal, according to Dahlan Iskan, one of Indonesian senior journalist as well as a media owner, is a news mission (Intarto, 2013, p. 126).

In order to fulfill this mission, environmental reporters need to have environmental awareness first. After that, they should always oversee the government's performance. If so, then we can hope that they can produce environmental news that can shape and enhance public environmental awareness.

As mentioned beforehand that the most important news feature to gain public interest is its comprehensiveness. However, the complete news is not enough. The experience of Agnes Aristiarini, an environmental reporter of Kompas daily, shows that the complete news is not necessarily able to increase public environmental awareness. She said, "No concern was 
detected, even though this daily has presented the problem of air pollution in full for years" (Abrar, 1997, p. 95).

Then, the task of environmental journalists is not easy. Environmental journalists need to know the existing environmental knowledge of the audiences. They should certainly know in advance about the needs of the general public. Also, they need to know how motivation works which can arise readers' participation. Fundamentally, the most important point is then keeping in the mind of environmental journalists to prioritize public interests.

However, reality shows that not all environmental journalists understand how to know the public needs. Wininda Qusnul Khotimah (2017, p. 121) who has studied the processes of environmental journalism in the Riau Pos daily, found that Riau Pos did not prioritize the interests of the community. Through the news, the public did not know the exact loss they suffered from the forest and land fires. The next result, they could not behave proportionally to the forest and land fires.

Suppose that environmental journalists are not able to know what are the public needs and interests. However, it does not mean that environmental reporters must be frustrated. Assuming that many people understand environmental issues are being reported, such as researchers, scholars or local leaders, the environmental journalist can invite them to criticize the environmental news. Therefore, the voice of the community is accommodated and they have the opportunity to be involved in the processes of news producing. In this way, environmental journalists can cover up the imperfect environmental journalism process.

In this context, Einsiedel \& Coughlan (1993, p. 134-135) ideas about three ways to make environmental news read by the general public will also be very helpful, namely reflecting people's attention, reporting government policy, and presenting national cultural products. Environmental news which is a reflection of the public's attention will jolt the general public. News about government policies will also attract the attention of the general public. While environmental news as a product of national culture will be able to set aside other news.

Nowadays, environmental reporters often perceive that public participation does not increase over time. They often feel desperate to see that the public cannot be invited to participate in maintaining environmental functions. Even though, according to Abrar $(2019, \mathrm{p}$. 11), the idea is still alive among environmental reporters, "They still expect the public to be willing to participate in preserving the environment. They still see this as an option for the practice of environmental journalism in Indonesia". Keeping such an idea makes sense because the environmental movement, such as "go green", day by day, showing its echoes. For example, SWA magazine (2016, p. 62) has reported:

Not only environmental activists, now almost all levels of society participate in green campaigns. This is certainly a breath of fresh air, considering that the 'cries' of non-governmental organizations will not be enough to solve a myriad of environmental problems, ranging from global warming, pollution, deforestation, to waste issues. 
Concern for the environment, according to Hannigan (1995), never remained. It fluctuates over time and periods. Thus, educating the public to care for the environment and practicing sustainable development is important whether or not the problem is. He continued, "Environmental problems do not materialize by themselves; rather, they must be constructed by individuals or organizations (Hannigan, 1995, p. 2). In this context, environmental journalists and the press play important roles in constructing environmental issues and maintaining environmental awareness of the public.

\section{e. Changing The Newsroom}

The efforts to apply better environmental journalism have actually been conducted among Indonesian journalists for some decades. However, according to Abrar (1995), one of the main problems is no Indonesian newspapers that have a special environmental desk. Furthermore, Abrar (1995, p. 36) has written:

Unfortunately, there are no newspapers in Indonesia that have an environmental desk, Kompas Daily and Suara Pembaruan Daily incorporating environmental news into the Science and Technology Desk. Therefore, this desk covers health, technology, and environmental news. Some regional newspapers do not even feel the need to have journalists specializing in the environment.

Up to this point, it can be concluded that the Indonesian press does not consider environmental issues as important issues that affect people's lives. As a result, the correct environmental journalism processes are not a top priority. Efforts to implement it are constrained by the attitude of the press itself.

The press, for example, would usually reject the idea of inviting people who understand environmental issues being reported to be involved in news reporting and writing. This idea, according to Harry Suryadi, a former Kompas daily reporter, was not fully acceptable to environmental journalists. Suryadi, in a personal communication (April 9, 2019) has noted, "There are journalists who are willing to implement it. There are also many journalists who reject it outright".

At this point, we may argue that there is a gap of thought between journalists and newsrooms. Then, of course, we need to change the mind of the gatekeepers who work in the newsroom. The problem is, as Yuval Noah Harari (2018, p. 407) has pointed out, "Changing the human mind is an extremely complicated and dangerous struggle". It seems also that journalists did not want to criticize the newsroom because of the influence of paternalism and collectivism, especially the attitude to prioritize group interests and maintain its harmony.

\section{CONCLUSION}

This paper has analyzed three news in the "environment" rubric of Tempo news magazine and treated this "environment" rubric as one of the indicators of environmental journalism development in Indonesia.

This study has found that Tempo preferred to present environmental news in the form of in-depth reporting. The news is written as comprehensive investigative reports on the environmental issues being reported, consumes significant pages of the magazine, and consists 
of three to four titles. Tempo has applied some writing strategies in order to catch the audience's attention, such as writing attractive leads, presenting detail descriptions, using multisided angles, focusing on answering "how" and "why" questions, and writing in thrifty, clear, narrative and colorful language styles.

This study has proposed some principles and techniques of environmental journalism. These insights were reflected from the Tempo environmental news, as well as from the general observations to the development of environmental journalism in Indonesia. First, a comprehensive report as a fundamental requirement of investigative journalism should also be applied in the environmental investigative news. The news should combine some information gathering methods and relate the environmental issues with social, politics, economics, and another aspect.

Second, environmental news should strongly have committed to biocentrism ethics and sustainable development principles. Tempo has displayed a commitment to biocentrism and sustainable development principles as the basis for determining news issues. Tempo saw how evil the government is towards nature, especially caused by their anthropocentrism standpoint in managing the environment. It could be the inspiration for journalists to look at environmental issues, everything goes against sustainable development principles that must be seen as something that will cause environmental problems.

Third, the duty of the environmental journalist is to criticize and push the government to apply sustainable development principles. While the main goal of environmental journalism is educating the public and increasing their environmental participation as well. In order to reach this goal, the environmental journalist should understand the public needs, interests, and levels of their environmental knowledge. With these understanding, the environmental journalist would be able to frame environmental issues, shaping public awareness about environmental issues, and increasing their participation in the environmental conservations. In the level of newsroom practices, it is very important to have a special desk of the environment in the newsroom in order to produce high quality environmental reports.

Finally, Tempo has implemented a series of techniques that are important for reporting environmental issues. Presumably, this can be used as a kind of technical guidelines for other print media in reporting environmental issues in Indonesia. This can also be an inspiration for those who want to take part in developing the techniques of reporting environmental issues.

\section{BIODATA}

Ana Nadhya Abrar is a senior lecturer of journalism at Gadjah Mada University, Yogyakarta, Indonesia and the author of Mengenal Jurnalisme Lingkungan Hidup (Understanding Environmental Journalism). He has written widely on political and business journalism. Email: ana.abrar@mail.ugm.ac.id 


\section{REFERENCES}

Abrar, A. N. (1995). Mengurai permasalahan jurnalisme (Explaining journalism problems). Jakarta, Indonesia: Pustaka Sinar Harapan.

Abrar, A. N. (1997). Bila fenomena jurnalisme direfleksikan (Reflecting journalism phenomena). Jakarta, Indonesia: Pustaka Sinar Harapan.

Abrar, A. N. (2019). Strengthening the role of environmental reporting in encouraging the participation of community in revitalizing the ecosystem: The case of Pulau Kelapa and Kepulauan Seribu, Indonesia (Unpublished article).

Aditjondro, G. J. (2003). Kebohongan-kebohongan negara: Perihal kondisi objektif lingkungan hidup di nusantara (State lies: Regarding objective environmental conditions in the nusantara archipelago). Yogyakarta, Indonesia: Pustaka Pelajar.

Anwar, H. R. (1984). Bahasa jurnalistik dan komposisi (Journalistic language and composition). Jakarta, Indonesia: Pradnya Paramita.

Aziz, T. (1992). Politik redaksional Surabaya Post: Panduan reporter (Editorial politics of Surabaya Post: Reporter guidelines). Surabaya, Indonesia: Surabaya Post.

Einsiedel, E., \& Coughlan, E. (1993). The Canadian Press and environment: Reconstructing a social reality. In A. Hansen (Ed.), The mass media and environmental issues (pp. 134-149). London, England: Leicester University Press.

Fletcher, F., \& Stahlbrand, L. (1992). Mirror or participant? The news media and environmental policy. In R. Boardman (Ed.), Canadian environmental policy: Ecosystems, politics, and process (pp. 179-199). Toronto, Canada: Oxford University Press.

Hannigan, J. A. (1995). Environmental sociology. London, England: Routledge.

Harari, Y. N. (2018). Homo Deus: Masa depan umat manusia (Homo Deus: The future of mankind). Jakarta, Indonesia: Pustaka Alvabet.

Holsti, O. R. (1969). Content analysis for the social sciences and humanities. London, England: Addison-Wesley Publishing Company.

Intarto, J. (2013). Akal sehat Dahlan Iskan: Catatan seorang murid (Common sense of Dahlan Iskan: A student's notes). Yogyakarta, Indonesia: JP Mitramedia.

Keraf, A. S. (2002). Etika lingkungan (Environmental ethics). Jakarta, Indonesia: Penerbit Buku Kompas.

Khotimah, W. Q. (2017). Proses jurnalisme lingkungan hidup di surat kabar: Studi deskriptif pada redaksi Riau Pos tentang pemberitaan kebakaran hutan dan lahan tahun 2017 (The processes of environmental journalism in newspapers: A descriptive study of the Riau Post newsroom in reporting forest and land fires in 2017) (Unpublished master thesis, Universitas Gadjah Mada, Yogyakarta, Indonesia).

Kurnia, S. S. (2009). Jurnalisme investigasi (Investigative journalism). Jakarta, Indonesia: Yayasan Obor Indonesia.

Oetama, J. (2001). Pers Indonesia: Berkomunikasi dalam masyarakat tidak tulus (Indonesian Press: Communicating in sincere society). Jakarta, Indonesia: Penerbit Buku Kompas.

Radar Jogja. (2019, February 1). Edukasi wong ndableg agar peduli lingkungan (Education for stubborn people to care for the environment), p. 7. 
Salim, E. (2013). Sekapur sirih: Lahirnya gagasan pembangunan berkelanjutan (Introduction: the birth of sustainable development idea). In S. T. Djajadiningrat \& S. Hardjolukito (Eds.), Demi bumi, demi kita (For the sake of the earth, for our sake) (pp. 8-11). Jakarta, Indonesia: Media Indonesia Publishing.

Salleh, K. O., \& Ghaffar, F. A. (2009). Climate change and its implications on poverty in Malaysia. Sarjana: Journal of the Faculty of Arts and Social Sciences University of Malaya, 24(1), 6382.

Silaningrum, R. (2017). Menakar jurnalisme investigasi Tempo: Analisis isi kualitatif berita investigasi majalah Tempo edisi 19-24 Desember 2016 tentang obral izin fakultas kedokteran (Measuring Tempo's investigative journalism: Qualitative content analysis of Tempo investigative reports concerning clearance sale of medical faculty permits in 1924 December 2016 Edition) (Unpublished undergraduate thesis, Universitas Gadjah Mada, Yogyakarta, Indonesia).

Sujito, A. (2013). Epilog: Masyarakat Indonesia dan tantangan perubahan (Epilogue: Indonesian society and the challenges to change). In Nasikun (Ed.), Sistem sosial Indonesia (Indonesian social system) (pp. 109-121). Yogyakarta, Indonesia: Ombak.

SWA. (2016, March 4-17). Aksi hijau memikat dari para pegiat lingkungan (Enchanting green action from the environmental activists), p. 62.

Tempo. (2011). Cerita di balik dapur Tempo 40 tahun (1971-2011) (Story behind the Tempo's newsroom for 40 years (1971-2011). Jakarta, Indonesia: PT Gramedia.

Tempo. (2016, March 7-13). Tentang narasumber yang tersembunyi (About hidden resources), pp. 32-33.

Tempo. (2018, November 26 - December 2). Hutan binasa, sawit tak ada (Perishable forests, no palm oil), pp. 46-51.

Tempo. (2019, February 18-24). Limbah berbahaya di markas tentara (Hazardous waste at the army headquarters), pp. 40-53.

Tempo. (2019, January 18-25). Malapateka limbah Freeport (The disaster of Freeport waste), pp.80-88.

The Asian Forum of Environmental Journalists. (1988). Reporting on the environmental: $A$ Handbook for journalists. Bangkok, Thailand: United Nations Economic and Social Commission for Asia and the Pacific (ESCAP). 